\title{
Células satélites musculares
}

\author{
Myogenic satellitecells
}

\author{
Rosália Maria Simões Antunes Foschini ${ }^{1}$ \\ Fernando Silva Ramalho ${ }^{2}$ \\ Harley E. A. Bicas ${ }^{3}$
}

Trabalho realizado no Hospital das Clínicas da Faculdade de Medicina de Ribeirão Preto da Universidade de São Paulo (USP).

${ }^{1}$ Médica assistente junto ao Setor de Estrabismo e Ortóptica do Hospital das Clínicas da Faculdade de Medicina de Ribeirão Preto (USP).

${ }^{2}$ Professor Doutor do Departamento de Cirurgia e Anatomia da Faculdade de Medicina de Ribeirão Preto (USP).

3 Professor Titular do Departamento de Oftalmologia, Otorrinolaringologia e Cabeça e Pescoço da Faculdade de Medicina de Ribeirão Preto (USP).

Endereço para correspondência: Departamento de Oftalmologia, HCFMRP - Ribeirão Preto (SP)

CEP 14048-900

E-mail: rantunes@keynet.com.br

\section{RESUMO}

O artigo descreve as células satélites musculares, marcadores, quantificação e distribuição, fatores de crescimento e hormônios envolvidos na sua regulação, interação com monócitos e macrófagos, respostas funcionais a estados fisiológicos e de doença, modelos genéticos de miopatia e de regeneração muscular, formação de músculo ectópico, formação do músculo e células precursoras, origem das células satélites, células periféricas, musculatura ocular externa e células satélites.

Descritores: Células satélites; Músculo esquelético; Fibra muscular; proteína MyoD, Músculo ocular externo

\section{INTRODUÇ̃̃̃O}

A musculatura esquelética de mamíferos adultos possui grande capacidade de adaptação a demandas fisiológicas, como no crescimento, no treinamento e no trauma. Sendo as fibras musculares esqueléticas adultas caracteristicamente bem diferenciadas, esse elevado potencial adaptativo é atribuído a uma população de células residentes no músculo esquelético adulto denominadas células satélites (CS).

\section{Identificação}

As CS musculares foram inicialmente descritas em 1961 em fibras musculares de rã ${ }^{(1)}$. Elas fazem parte de uma população de células com grande atividade mitogênica que contribuem para o crescimento muscular pósnatal, o reparo de fibras musculares danificadas e a manutenção do músculo esquelético adulto. Foram assim denominadas por sua localização anatômica na periferia de fibras musculares multinucleadas maduras. São células indiferenciadas e mononucleadas, cuja membrana basal está em continuidade com a membrana basal da fibra muscular. Enquanto o tecido muscular esquelético mantém-se livre de agressões, as CS permanecem em estado de quiescência (repouso). Entretanto, em resposta a estímulos como crescimento, remodelação ou trauma, as CS são ativadas, proliferam-se e expressam marcadores da linhagem miogênica. Neste estado, também são denominadas mioblastos. Essas células se fundem a fibras musculares já existentes ou se fundem a CS vizinhas para gerar novas fibras musculares. Há evidências de que as CS constituem uma população bastante heterogênea, visto que algumas podem sofrer diferenciação imediata, sem divisão prévia, enquanto outras primeiramente proliferam, gerando uma célula filha para diferenciação e outra para futura proliferação ${ }^{(2)}$. Recente estudo demonstrou que apenas $50 \%$ das CS que proliferam entram em fase final de diferenciação, expressando a proteína miosina do desenvolvimento ${ }^{(3)}$.

Morfologicamente, as CS quiescentes diferem das ativadas por apresentarem alta relação núcleo/citoplasma, com poucas organelas, núcleo 
menor quando comparado com os núcleos adjacentes da fibra muscular e aumento da heterocromatina nuclear comparada à do mionúcleo. Quando ativadas, ocorre redução da heterocromatina, aumento na relação citoplasma/núcleo e aumento no número de organelas intracelulares ${ }^{(4)}$.

Em estudos com cultura de células, observou-se que as CS humanas movimentam-se e apresentam uma taxa constante de migração(5).

\section{Marcadores}

O padrão de expressão gênica das CS ainda é pouco conhecido, tanto no estado de quiescência como no estado ativado. As CS quiescentes não expressam fatores reguladores da miogênese das famílias do MyoD, MEF2 ou outros marcadores de diferenciação terminal.

São conhecidos marcadores para as CS:

2a) $M y o D$ - descoberto em 1987, o MyoD é um fator de transcrição que pertence à família de proteínas "basic helixloop-helix". Essa família de proteínas "basic helix-loophelix", que também inclui outras proteínas (como o Myf-5, a miogenina e o MRF4), controla a diferenciação de células da linhagem miogênica. CS MyoD negativas apresentam capacidade de diferenciação reduzida e retardada ${ }^{(6-7)}$. O MyoD é um excelente marcador para CS ativadas ${ }^{(8-9)}$, sendo encontrado em elevados níveis no músculo em regeneração e de neona$\operatorname{tos}^{(10)}$. O papel funcional do MyoD na musculatura esquelética após o nascimento ainda não é claro. Sua detecção ocorre doze horas após um traumatismo muscular, juntamente com outras proteínas relacionadas com a diferenciação de células da linhagem miogênica, como desmina e miogenina ${ }^{(2)}$. Em relação às fases do ciclo celular, o MyoD apresenta-se em altos níveis durante a fase G1 da interfase, quando tem início a diferenciação celular, caindo para níveis baixos na transição G1/S, e novamente aumentando no transcorrer da fase S para a mitose propriamente dita ${ }^{(11)}$.

2b) $\boldsymbol{M y f - 5}$ - é um fator de transcrição que pertence à família de proteínas "basic helix-loop helix”. Marca CS quiescentes $^{(12)}$ e ativadas ${ }^{(13)}$. O Myf-5 encontra-se em níveis elevados durante a fase de repouso (G0), decresce durante G1, mas reaparece ao final de G1, para se manter estável até ocorrer nova mitose ${ }^{(11)}$.

2c) $\boldsymbol{M N F}$ - também conhecido como Foxk1, o MNF é um fator de transcrição da família “winged helix". Encontra-se presente em CS de músculo esquelético adulto. São conhecidas duas isoformas, o MNF- $\alpha$ e o MNF-ß. O MNF- $\alpha$ é identificado predominantemente em células em proliferação após trauma, enquanto o MNF-ß é a principal isoforma expressa em células quiescentes. Uma ruptura do “locus” do MNF resulta em importante déficit de crescimento e grande dificuldade para regeneração muscular ${ }^{(14)}$.

2d) $\boldsymbol{c}$-Met - a proteína produzida pelo gene c-Met é um receptor de superfície celular para o fator de crescimento do hepatócito (HGF), um potente mitógeno para as CS. O c-Met tem atividade tirosina-quinase. Cornelison e Wold ${ }^{(8)}$ demonstraram que o c-Met é um marcador de CS quiescentes e ativadas, capaz de identificar fibras musculares, mas não fibroblastos musculares. Embriões deficientes em c-Met falham na formação da musculatura esquelética dos membros devido à falta de células precursoras da linhagem miogênica ${ }^{(15-16)}$. Em cultura de CS de galinhas, há descrição de diminuição nos níveis de c-met m-RNA durante a diferenciação celular ${ }^{(17)}$.

2e) $\boldsymbol{M}$-cadherin - é uma molécula de adesão celular dependente de cálcio, cuja função está relacionada à mediação entre duas células, com importância para a manutenção da estrutura e morfogênese celulares. Sua expressão ocorre em uma subpopulação de CS quiescentes, estando aumentada quando as CS se tornam ativadas em presença de um estímulo. Sua função não é muito clara, mas juntamente com outras moléculas de adesão celular, como a N-CAM ("neural cell adhesion molecule”) e a VCAM-1 ("vascular adhesion molecule 1"), que são potenciais marcadores para as CS quiescentes, podem ajudar na adesão das CS à lâmina basal da miofibra e podem participar na capacidade migratória dessas células em resposta a um estímulo ${ }^{(14)}$.

2f) Pax7 - é um fator de transcrição “paired box” expresso em CS quiescentes e em proliferação. Uma mutação no Pax7 leva à ausência de CS, mostrando que o Pax7 é extremamente importante para a especificação da população de $\mathrm{CS}^{(18)}$.

2g) Miogenina - é um fator regulador da miogênese que se encontra expresso em CS ativadas e mioblastos ${ }^{(19)}$.

2h) PCNA - o PCNA ("proliferating cell nuclear antigen”) é uma proteína cuja síntese ocorre no início das fases G1 e $\mathrm{S}$ do ciclo celular. Embora inespecífico, é um excelente marcador para células em proliferação, inclusive as $\operatorname{CS}^{(3)}$.

2i) Ki-67 - é um marcador presente nas fases S, G2 e M do ciclo celular, mas ausente em G0. Uma vez tendo início a diferenciação celular, a sua expressão também declina. Também não é específico para as células musculares ${ }^{(20)}$.

2j) Sox 8 - pertence à família dos reguladores da transcrição. Sua expressão é intensa durante o desenvolvimento embrionário e gradualmente decresce após o nascimento. O Sox 8 está confinado às CS, e sua expressão está relacionada ao bloqueio da diferenciação da célula muscular ${ }^{(21)}$.

2l) CD34 - o CD34 é uma glicoproteína transmembrana presente na superfície de células progenitoras, células endoteliais de pequenos vasos, fibroblastos embrionários e algumas células de tecido neural fetal e adulto. Sua expressão é mais intensa nas células tronco primitivas, tornando-se gradualmente menos intensa à medida que ocorre a diferenciação celular. O CD34 também está presente em células endoteliais de capilares e em células estromais da medula óssea. Marca CS quiescentes $^{(22)}$.

2m) Proteínas músculo-específicas - CS de músculo bíceps femural de cães adultos ${ }^{(22)}$ expressam proteínas músculo-específicas, como actina, miosina e desmina ${ }^{(23)}$, além de N-CAM, MyoD e miogenina. Células musculares embrionárias de coelhos foram marcadas com anticorpos para as isoformas embrionária e perinatal da cadeia pesada da miosina ${ }^{(24)}$. Clones de CS de músculo quadríceps de humanos expressam a cadeia pesada da miosina, tanto a isoforma lenta como a rápida ${ }^{(25)}$. 
2n) c-ski - é uma proteína nuclear importante no controle da proliferação e diferenciação das células do músculo esquelético. Durante a regeneração muscular, ocorre aumento na expressão da c-ski, sendo muitas células também positivas para PCNA e desmina ${ }^{(26)}$.

2o) p27 kip - há uma relação inversa entre a capacidade proliferativa da CS e a abundância da proteína p27 Kip, podendo estar envolvida no crescimento e na hipertrofia musculares ${ }^{(27)}$.

2p) $v$-Src - é uma típica tirosina-quinase, inibindo a diferenciação miogênica por meio da inibição da expressão de MyoD e miogenina ${ }^{(28)}$.

Outros candidatos a marcadores das CS encontram-se em investigação: o antígeno de superfície celular Sca-1(29-30), a glicoproteína Leu-19, o fator anti-apoptótico Bcl-2 ${ }^{(31-32)}$, entre outros.

\section{Quantificação e distribuição}

Em ratos, as CS constituem cerca de $30 \%$ dos núcleos no músculo do neonato e decrescem para cerca de $4 \%$ no adulto e $2 \%$ no idoso ${ }^{(33-34)}$. Com o envelhecimento, há aumento no número de mionúcleos e decréscimo no número de $\mathrm{CS}^{(34)}$. O número de CS também é dependente da espécie e do tipo de fibra muscular. Em relação à fibra muscular, há aumento na densidade de CS em associação à proximidade de capilares, número de mionúcleos e de junções mioneurais. As fibras oxidativas, caracterizadas pelo aumento na densidade de motoneurônios e capilares em relação às fibras glicolíticas, demonstram um conteúdo de CS cinco a seis vezes maior ${ }^{(35-36)}$. As fibras musculares rápidas contêm um menor número de CS em comparação às fibras musculares lentas, produzindo também menos mioblastos ${ }^{(37)}$. As CS provenientes de fibras lentas proliferam-se, fundem-se e amadurecem mais rápido ${ }^{(38)}$, e podem ter papéis diferentes na formação e diferenciação de fibras rápidas e lentas ${ }^{(39)}$.

\section{Fatores de crescimento como reguladores das CS}

Os estudos com fatores de crescimento foram feitos, em sua maioria, em culturas de CS, apresentando algumas limitações devido à falta de fatores permissivos ou repressivos que poderiam estar presentes in vivo e que poderiam influenciar a atividade celular.

4a) HGF - o fator de crescimento do hepatócito (HGF) é uma glicoproteína com múltiplas funções, inicialmente descrita como um potente mitógeno para hepatócitos maduros. É capaz de ativar e induzir a proliferação de CS. Entretanto, o HGF reduz a diferenciação das CS por meio da inibição da transcrição de fatores reguladores da miogênese ${ }^{(17)}$ e do inibidor do ciclo celular p $27^{(40)}$. Sua expressão é proporcional ao grau de lesão muscular ${ }^{(8)}$. O estiramento mecânico induz a ativação das CS em cultura, com liberação de HGF. Dessa forma, o HGF pode estar envolvido na ativação das CS após uma perturbação mecânica ${ }^{(41)}$.

4b) FGF - os fatores de crescimento de fibroblastos (FGF) constituem uma família de proteínas que controlam o crescimento e diferenciação de células mesenquimais, epiteliais e ectodérmicas. Os FGF estimulam a síntese de tecido conjuntivo, induzem a proliferação de CS e suprimem a diferenciação miogênica. O FGF-1 caracteriza-se por exacerbar a atividade proliferativa de mioblastos. Os níveis dos FGF são proporcionais ao grau de expressão dos seus receptores. Quando ocorre um aumento na expressão dos receptores para o FGF, há aumento na proliferação e redução na diferenciação de $\mathrm{CS}^{(42)}$. Os níveis dos FGF encontram-se elevados em pacientes com distrofia muscular de Duchenne ${ }^{(43)}$.

4c) IGF - os fatores de crescimento semelhantes à insulina (“IGF - insulin-like growth factor”) são proteínas importantes no controle do metabolismo da insulina, além de regularem a regeneração muscular. Os IGF-I e IGF-II estimulam a proliferação e a diferenciação de CS in vitro ${ }^{(14)}$.

4d) TGF- $\beta$ - os membros da família do TGF- $ß$ (“ $\beta$ transforming growth factor") geralmente inibem a proliferação e diferenciação musculares, inibindo a transcrição de genes da família $\mathrm{MyoD}^{(14)}$.

\section{Hormônios como reguladores das células satélites}

5a) Insulina - em cultura de células, a insulina constituise num efetivo mitógeno para as CS de músculo semimembranoso de bovinos, induzindo proliferação, formação de miotubos e diferenciação celular ${ }^{(4)}$.

5b) Triiodotironina (T3) - o T3 reduz a proliferação de CS de forma dose dependente ${ }^{(44)}$.

\section{Interação com monócitos e macrófagos}

In vitro, a interação das CS com monócitos e macrófagos estimula a proliferação dos mioblastos e das CS por meio de fatores solúveis ${ }^{(45)}$, além de protegê-los da apoptose ${ }^{(46)}$. Entretanto, a diferenciação das CS é retardada pelos macrófagos ${ }^{(47)}$.

\section{Respostas funcionais a estímulos fisiológicos}

7a) Hipertrofia muscular - exercícios de resistência induzem hipertrofia muscular por meio da ativação e da proliferação de CS, com posterior quimiotaxia e fusão das CS às fibras musculares pré-existentes ${ }^{(4)}$. Exercícios de estiramento também podem levar à hipertrofia muscular, com conseqüente aumento do número de CS, aumento da área seccional da fibra e do número de mionúcleos ${ }^{(48-50)}$. Recentes investigações sugerem que exercícios freqüentes podem aumentar o número de fibras musculares (hiperplasia), embora seu efeito na área seccional da fibra muscular seja pequeno. As CS parecem estar envolvidas neste fenômeno ${ }^{(51-52)}$. A testosterona conduz à hipertrofia muscular, alterando o número de mionúcleos, o número de CS e a massa adiposa. Uma possível explicação para a hipertrofia muscular seria o efeito estimulante da testosterona sobre as células tronco da linhagem miogênica, inibindo a diferenciação da linhagem adipogênica ${ }^{(53)}$. Em homens que receberam suplementação de testosterona, observou-se hipertrofia muscular associada a aumento de CS e aumento proporcional do número de mionúcleos com mudanças em sua ultraestrutura ${ }^{(48,54)}$. Lowe e Alway ${ }^{(55)}$, entretanto, 
demonstraram hipertrofia em músculos de asa de codornas, apesar da ausência de CS em atividade proliferativa.

7b) Hiperplasia muscular - a hiperplasia muscular foi observada em modelos experimentais de levantamento de peso em ratos, em que foram evidentes a regeneração das fibras musculares e a formação de novas miofibras (hiperplasia) no espaço intersticial ${ }^{(56)}$. O surgimento de novas fibras musculares pode ocorrer a partir de células que expressam o antígeno CD 34, distintamente das $\mathrm{CS}^{(56)}$.

7c) Atrofia muscular - a atrofia muscular conduz à diminuição do número de mionúcleos, podendo ser secundária a desnervação, nutrição deficiente ou imobilização do músculo. Em um modelo com ratos pré-púberes, a imobilização de um músculo levou à diminuição do número e da capacidade proliferativa das CS, alterando irreversivelmente a remodelação muscular, fato que não ocorreu em animais adultos, nos quais as CS proliferaram e repopularam o músculo atrófico ${ }^{(57)}$. Quando sofrem desnervação, as CS aumentam em número na fase aguda, para, depois, numa fase crônica, ocorrer um decréscimo significativo das mesmas. As CS presentes em músculo desnervado expressam Myfs e muito fracamente miogenina e MRF4, indicando seu estado quiescente ${ }^{(58)}$.

7d) Envelhecimento - a eficiência das CS em proliferar e se diferenciar é dependente da idade do indivíduo. Quanto maior a idade, menor a capacidade de proliferação e de diferenciação das $\operatorname{CS}^{(59-60)}$.

\section{Respostas funcionais a estados de doença}

Diversas miopatias são secundárias a uma mutação molecular que irá afetar as proteínas musculares, resultando em alterações estruturais no músculo esquelético. A distrofia muscular de Duchenne (DMD) é a mais comum e a mais devastadora das miopatias. A mutação num gene relacionado a uma proteína do citoesqueleto da fibra muscular a torna extremamente frágil, e os traumatismos constantes levam a contínuos ciclos de degeneração-regeneração, culminando com a exaustão do "pool” de CS. Duas possíveis explicações para a progressão da DMD são o envelhecimento das CS após sucessivas replicações, ou o retardo no processo de diferenciação celular ${ }^{(60-61)}$. Renault et al. ${ }^{(60)}$ demonstraram que a sobrevida das CS oriundas de um paciente de nove anos com DMD era aproximadamente um terço da sobrevida de CS de um indivíduo saudável com a mesma idade.

\section{Modelos genéticos de miopatia em ratos}

Linhagens de ratos portadores de miopatia, mutantes para a produção de distrofina, utrofina, MyoD ou MNF, exibem graves miopatias, apresentando, à semelhança da DMD em humanos, CS com menor sobrevida e prejuízo da capacidade regenerativa. Nicole et al. ${ }^{(62)}$ e Furling et al ${ }^{(63)}$ demonstraram que CS oriundas de ratos normais aumentam muito a sobrevida de ratos mutantes portadores de miopatia crônica, embora pareça haver um potencial limitado para a regeneração da musculatura esquelética. As CS provenientes de hamsters distróficos irão originar miotubos anormais ${ }^{(64)}$.

\section{Modelos de regeneração muscular}

Existem vários modelos de regeneração muscular que objetivam o estudo do processo de ativação das CS. Um dos modelos mais estudados consiste na injeção da cardiotoxina, originada do veneno de uma serpente, cuja injeção no músculo gastrocnêmio leva à degeneração de cerca de 80 a 90\% das fibras musculares. Seis horas após a lesão, as CS tornam-se ativadas, proliferando durante 2 a 3 dias $^{(65-66)}$. A regeneração muscular completa ocorre em cerca de dez dias.

\section{Formação de músculo esquelético ectópico}

A partir de mioblastos implantados no tecido subcutâneo de ratos, Irintchev et al ${ }^{(67)}$ demonstraram a formação de músculo esquelético ectópico, dotado de contratilidade espontânea ou eletricamente induzida, e com morfologia e fenótipo de tecido muscular esquelético maduro.

\section{Formação do músculo esquelético por células precursoras}

Os mecanismos anatômicos e moleculares envolvidos na regeneração muscular parecem recapitular os ocorridos no desenvolvimento.

Durante a embriogênese, a cabeça, o tronco e os membros desenvolvem-se como linhagens diferentes. A mesoderme paraxial origina os somitos, que se subdividem em somitos dorsomediais (epaxial), originando os músculos dorsais, e somitos ventromediais (hipaxial), originando os músculos abdominais, intercostais e dos membros. Durante a somitogênese, fatores de crescimento e fatores de transcrição interagem, de modo que o somito e estruturas adjacentes (ectoderme adjacente, tubo neural e notocorda e estruturas vasculares, incluindo a aorta), resultarão no tecido muscular após uma série de reações moleculares ${ }^{(14)}$.

\section{Células precursoras musculares e desenvolvimento dos membros}

Antes da migração das células precursoras musculares para os locais onde serão formados os membros, estas não são capazes de expressar proteínas da família MyoD. Após a migração destas células para o membro em desenvolvimento é que tem início a expressão das proteínas da família MyoD. Os mioblastos localizados nos membros irão sofrer coalescência, formando massas pré-musculares, que posteriormente originarão fibras musculares multinucleadas.

\section{Origem das células satélites (Somítica versus não somítica)}

A origem das CS ainda não está definida. Há uma hipótese de que elas se originem de células pluripotenciais da mesoderme dos somitos ${ }^{(14)}$. Outros estudos sugerem que as CS são derivadas de células pluripotenciais de origem não somítica, como as células endoteliais ${ }^{(68)}$. 


\section{Células satélites e células periféricas ("Side population cells")}

Além das CS, o músculo estriado esquelético possui outra população de células tronco, denominadas células periféricas ("side population cells")(69-71). Estas células são capazes de gerar miócitos ou CS após transplante intramuscular, mas não conseguem fazê-lo in vitro. Enquanto as CS são negativas para os marcadores Sca-1 e CD 45, as células periféricas expressam o Sca-1 e o CD45, um conhecido marcador de células tronco hematopoiéticas. Após serem transplantadas, as células periféricas podem se diferenciar em células hematopoiéti$\operatorname{cas}^{(29,72)}$, fibras musculares ou CS, participando, dessa forma, da regeneração muscular ${ }^{(73-74)}$.

Outros estudos são necessários para determinar se as células periféricas são precursoras das CS, ou se são uma subpopulação delas, ou se são uma população de células tronco independente e também residente no tecido muscular esquelético.

\section{Células satélites e a musculatura ocular externa}

McLoon e Wirtschafter descreveram, em fibras da musculatura ocular externa de $\operatorname{coelhos}^{(75)}$, macacos e humanos ${ }^{(76)}$, adultos e sem trauma, cerca de 2 a $4 \%$ de CS positivas para o MyoD, demonstrando também a adição de novos mionúcleos às fibras pré-existentes em ratos e coelhos ${ }^{(75,77)}$, sugerindo que a musculatura ocular externa está em contínua renovação, fato não encontrado em músculo esquelético adulto proveniente dos membros ${ }^{(78)}$, onde a marcação pelo MyoD é inexistente. Outros marcadores para as CS também foram evidenciados, como o Pax7, a miogenina e o $\mathrm{HGF}^{(76)}$. Em recente trabalho(79) também se demonstrou haver renovação de mionúcleos, além de evidências de apoptose celular. A musculatura ocular externa de coelhos também mostrou-se influenciada pela ação do fator de crescimento IGF-II ${ }^{(80)}$, resultando em aumento da força muscular, embora sem alterações significativas na área seccional das fibras. Esses achados podem ser o caminho para futuras investigações tanto para o tratamento como para a etiologia do estrabismo, patologia associada ao desequilíbrio de forças da musculatura ocular externa, em grande parte dos casos ainda sem etiologia definida.

\section{ABSTRACT}

The article describes myogenic satellite cells, their markers, quantification and distribution, growth factors and hormones involved in their regulation, interaction with macrophages and monocytes, functional answers to physiologic stimuli/disease states, genetic models of myopathies and muscular regeneration, ectopic muscle formation, muscle formation and precursor cell, satellite cell origin, peripheral cells, extraocular muscles and satellite cells.

Keywords: Satellite cells, Skeletal muscle; Muscle fibers; MyoD protein; Regeneration; Growth substances; Myogenic regulatory factors

\section{REFERÊNCIAS}

1. Mauro A. Satellite cell of skeletal muscle fibers. J Biophys Biochem Cytol. 1961;9:493-5.

2. Rantanen J, Hurme T, Lukka R, Heino J, Kalimo H. Satellite cell proliferation and the expression of myogenin and desmin in regenerating skeletal muscle: evidence for two different populations of satellite cells. Lab Invest. 1995;72(3):341-7.

3. Yablonka-Reuveni Z, Rivera AJ. Temporal expression of regulatory and structural muscle proteins during myogenesis of satellite cells on isolated adult rat fibers. Dev Biol. 1994;164(2):588-603.

4. Schultz E, McCormick KM. Skeletal muscle satellite cells. Rev Physiol Biochem Pharmacol. 1994;123:213-57.

5. Chazaud B, Christov C, Gherardi RK, Barlovatz-Meimon G. In vitro evaluation of human muscle satellite cell migration prior to fusion into myotubes. J Muscle Res Cell Motil. 1998;19(8):931-6.

6. Cornelison DD, Olwin BB, Rudnicki MA, Wold BJ. MyoD(-/-) satellite cells in single-fiber culture are differentiation defective and MRF4 deficient. Dev Biol. 2000;224(2):122-37.

7. Yablonka-Reuveni Z, Rudnicki MA, Rivera AJ, Primig M, Anderson JE, Natanson P. The transition from proliferation to differentiation is delayed in satellite cells from mice lacking MyoD. Dev Biol. 1999;210(2):440-55.

8. Cornelison DD, Wold BJ. Single-cell analysis of regulatory gene expression in quiescent and activated mouse skeletal muscle satellite cells. Dev Biol. 1997;191(2):270-83.

9. Megeney LA, Kablar B, Garrett K, Anderson JE, Rudnicki MA. MyoD is required for myogenic stem cell function in adult skeletal muscle. Genes Dev. 1996;10(10):1173-83.

10. Koishi K, Zhang M, McLennan IS, Harris AJ. MyoD protein accumulates in satellite cells and is neurally regulated in regenerating myotubes and skeletal muscle fibers. Dev Dyn. 1995;202(3):244-54.

11. Kitzmann M, Carnac G, Vandromme M, Primig M, Lamb NJ, Fernandez A. The muscle regulatory factors MyoD and myf-5 undergo distinct cell cyclespecific expression in muscle cells. J Cell Biol. 1998;142(6):1447-59.

12. Beauchamp JR, Heslop L, Yu DS, Tajbakhsh S, Kelly RG, Wernig A, et al. Expression of CD34 and Myf5 defines the majority of quiescent adult skeletal muscle satellite cells. J Cell Biol. 2000;151(6):1221-34.

13. Cooper RN, Tajbakhsh S, Mouly V, Cossu G, Buckingham M, Butler-Browne GS. In vivo satellite cell activation via Myf5 and MyoD in regenerating mouse skeletal muscle. J Cell Sci. 1999;112(Pt 17):2895-901.

14. Hawke TJ, Garry DJ. Myogenic satellite cells: physiology to molecular biology. J Appl Physiol. 2001;9(2):534-51.

15. Bladt F, Riethmacher D, Isenmann S, Aguzzi A, Birchmeier C. Essential role for the c-met receptor in the migration of myogenic precursor cells into the limb bud. Nature. 1995;376(6543):768-71. Comment in: Nature. 1995;376(6543):723.

16. Maina F, Casagranda F, Audero E, Simeone A, Comoglio PM, Klein R, et al. Uncoupling of Grb2 from the Met receptor in vivo reveals complex roles in muscle development. Cell. 1996;87(3):531-42.

17. Gal-Levi R, Leshem Y, Aoki S, Nakamura T, Halevy O. Hepatocyte growth factor plays a dual role in regulating skeletal muscle satellite cell proliferation and differentiation. Biochim Biophys Acta. 1998;1402(1):39-51.

18. Seale P, Sabourin LA, Girgis-Gabardo A, Mansouri A, Gruss P, Rudnicki MA. Pax7 is required for the specification of myogenic satellite cells. Cell. 2000;102(3):777-86.

19. Grounds MD, Garrett KL, Lai MC, Wright WE, Beilharz MW. Identification of skeletal muscle precursor cells in vivo by use of MyoD1 and myogenin probes. Cell Tissue Res. 1992;267(1):99-104.

20. Gerdes J, Lemke H, Baisch H, Wacker HH, Schwab U, Stein H. Cell cycle analysis of a cell proliferation-associated human nuclear antigen defined by the monoclonal antibody Ki-67. J Immunol. 1984;133(4):1710-5.

21. Schmidt K, Glaser G, Wernig A, Wegner M, Rosorius O. Sox8 is a specific marker for muscle satellite cells and inhibits myogenesis. J Biol Chem. 2003; 278(32):29769-75.

22. Michal J, Xiang Z, Davenport G, Hayek M, Dodson MV, Byrne KM. Isolation and characterization of canine satellite cells. In Vitro Cell Dev Biol Anim. 2002;38(8):467-80.

23. Lawson-Smith MJ, McGeachie JK. The identification of myogenic cells in skeletal muscle, with emphasis on the use of tritiated thymidine autoradiography and desmin antibodies. J Anat. 1998;192(Pt 2):161-71.

24. Barjot C, Cotten ML, Goblet C, Whalen RG, Bacou F. Expression of myosin heavy chain and of myogenic regulatory factor genes in fast or slow rabbit muscle satellite cell cultures. J Muscle Res Cell Motil. 1995;16(6):619-28. 
25. Edom F, Mouly V, Barbet JP, Fiszman MY, Butler-Browne GS. Clones of human satellite cells can express in vitro both fast and slow myosin heavy chains. Dev Biol. 1994;164(1):219-29.

26. Soeta C, Suzuki M, Suzuki S, Naito K, Tachi C, Tojo H. Possible role for the c-ski gene in the proliferation of myogenic cells in regenerating skeletal muscles of rats. Dev Growth Differ. 2001;43(2):155-64.

27. Spangenburg EE, Chakravarthy MV, Booth FW. p27Kip1: a key regulator of skeletal muscle satellite cell proliferation. Clin Orthop. 2002(403 Suppl):S221-7.

28. Falcone G, Ciuffini L, Gauzzi MC, Provenzano C, Strano S, Gallo R, et al. vSrc inhibits myogenic differentiation by interfering with the regulatory network of muscle-specific transcriptional activators at multiple levels. Oncogene. 2003;22(51):8302-15

29. Jackson KA, Mi T, Goodell MA. Hematopoietic potential of stem cells isolated from murine skeletal muscle. Proc Natl Acad Sci USA. 1999;96(25):14482-6. Comment in: Proc Natl Acad Sci USA. 1999;96(25):14193-5.

30. Spangrude GJ, Heimfeld S, Weissman IL. Purification and characterization of mouse hematopoietic stem cells. Science. 1988;241(4861):58-62. Erratum in: Science. 1989:244(4908):1030.

31. Lee JY, Qu-Petersen Z, Cao B, Kimura S, Jankowski R, Cummins J, et al. Clonal isolation of muscle-derived cells capable of enhancing muscle regeneration and bone healing. J Cell Biol. 2000;150(5):1085-100.

32. Miller JB, Schaefer L, Dominov JA. Seeking muscle stem cells. Curr Top Dev Biol. 1999;43:191-219.

33. Snow MH. The effects of aging on satellite cells in skeletal muscles of mice and rats. Cell Tissue Res. 1977;185(3):399-408.

34. Decary S, Mouly V, Hamida CB, Sautet A, Barbet JP, Butler-Browne GS. Replicative potential and telomere length in human skeletal muscle: implications for satellite cell-mediated gene therapy. Hum Gene Ther. 1997;8(12):1429-38.

35. Gibson MC, Schultz E. The distribution of satellite cells and their relationship to specific fiber types in soleus and extensor digitorum longus muscles. Anat Rec. 1982;202(3):329-37.

36. Schmalbruch H, Hellhammer U. The number of nuclei in adult rat muscles with special reference to satellite cells. Anat Rec. 1977;189(2):169-75.

37. Zammit PS, Heslop L, Hudon V, Rosenblatt JD, Tajbakhsh S, Buckingham $\mathrm{ME}$, et al. Kinetics of myoblast proliferation show that resident satellite cells are competent to fully regenerate skeletal muscle fibers. Exp Cell Res. 2002;281(1): 39-49.

38. Barjot C, Laplace-Marieze V, Gannoun-Zaki L, McKoy G, Briand M, Vigneron $\mathrm{P}$, et al. Expression of lactate dehydrogenase, myosin heavy chain and myogenic regulatory factor genes in rabbit embryonic muscle cell cultures. J Muscle Res Cell Motil. 1998;19(4):343-51.

39. Martelly I, Soulet L, Bonnavaud S, Cebrian J, Gautron J, Barritault D. Differential expression of FGF receptors and of myogenic regulatory factors in primary cultures of satellite cells originating from fast (EDL) and slow (Soleus) twitch rat muscles. Cell Mol Biol.(Noisy-le-grand) 2000;46(7):1239-48.

40. Leshem Y, Spicer DB, Gal-Levi R, Halevy O. Hepatocyte growth factor (HGF) inhibits skeletal muscle cell differentiation: a role for the bHLH protein twist and the cdk inhibitor p27. J Cell Physiol. 2000;184(1):101-9.

41. Tatsumi R, Sheehan SM, Iwasaki H, Hattori A, Allen RE. Mechanical stretch induces activation of skeletal muscle satellite cells in vitro. Exp Cell Res. 2001;267(1):107-14.

42. Scata KA, Bernard DW, Fox J, Swain JL. FGF receptor availability regulates skeletal myogenesis. Exp Cell Res. 1999;250(1):10-21.

43. D’Amore PA, Brown RH, Jr., Ku PT, Hoffman EP, Watanabe H, Arahata K, et al. Elevated basic fibroblast growth factor in the serum of patients with Duchenne muscular dystrophy. Ann Neurol. 1994;35(5):362-5. Commented in: Ann Neurol. 1994;36(5):800.

44. Cassar-Malek I, Langlois N, Picard B, Geay Y. Regulation of bovine satellite cell proliferation and differentiation by insulin and triiodothyronine. Domest Anim Endocrinol. 1999;17(4):373-88.

45. Cantini M, Carraro U. Macrophage-released factor stimulates selectively myogenic cells in primary muscle culture. J Neuropathol Exp Neurol. 1995;54(1)121-8.

46. Chazaud B, Sonnet C, Lafuste P, Bassez G, Rimaniol AC, Poron F, et al. Satellite cells attract monocytes and use macrophages as a support to escape apoptosis and enhance muscle growth. J Cell Biol. 2003;163(5):1133-43.

47. Merly F, Lescaudron L, Rouaud T, Crossin F, Gardahaut MF. Macrophages enhance muscle satellite cell proliferation and delay their differentiation. Muscle Nerve. 1999;22(6):724-32.

48. Kadi F, Eriksson A, Holmner S, Thornell LE. Effects of anabolic steroids on the muscle cells of strength-trained athletes. Med Sci Sports Exerc. 1999;31 (11):1528-34.

49. Hikida RS, Staron RS, Hagerman FC, Walsh S, Kaiser E, Shell S, et al. Effects of high-intensity resistance training on untrained older men. II. Muscle fiber characteristics and nucleo-cytoplasmic relationships. J Gerontol A Biol Sci Med Sci. 2000;55(7):B347-54.

50. Dodson MV, McFarland DC, Grant AL, Doumit ME, Velleman SG. Extrinsic regulation of domestic animal-derived satellite cells. Domest Anim Endocrinol. 1996;13(2):107-26.

51. Abernethy PJ, Jurimae J, Logan PA, Taylor AW, Thayer RE. Acute and chronic response of skeletal muscle to resistance exercise. Sports Med. 1994; 17(1):22-38.

52. Antonio J, Gonyea WJ. Skeletal muscle fiber hyperplasia. Med Sci Sports Exerc. 1993;25(12):1333-45.

53. Bhasin S, Taylor WE, Singh R, Artaza J, Sinha-Hikim I, Jasuja R, et al. The mechanisms of androgen effects on body composition: mesenchymal pluripotent cell as the target of androgen action. J Gerontol A Biol Sci Med Sci. 2003;58(12):M1103-10.

54. Sinha-Hikim I, Roth SM, Lee MI, Bhasin S. Testosterone-induced muscle hypertrophy is associated with an increase in satellite cell number in healthy, young men. Am J Physiol Endocrinol Metab. 2003;285(1):E197-205.

55. Lowe DA, Alway SE. Stretch-induced myogenin, MyoD, and MRF4 expression and acute hypertrophy in quail slow-tonic muscle are not dependent upon satellite cell proliferation. Cell Tissue Res. 1999;296(3):531-9.

56. Tamaki T, Akatsuka A, Yoshimura S, Roy RR, Edgerton VR. New fiber formation in the interstitial spaces of rat skeletal muscle during postnatal growth. J Histochem Cytochem. 2002;50(8):1097-111.

57. Mozdziak PE, Pulvermacher PM, Schultz E. Unloading of juvenile muscle results in a reduced muscle size 9 wk after reloading. J Appl Physiol. 2000;88(1):158-64.

58. Maier A, Zhou Z, Bornemann A. The expression profile of myogenic transcription factors in satellite cells from denervated rat muscle. Brain Pathol. 2002;12(2):170-7.

59. Charge SB, Brack AS, Hughes SM. Aging-related satellite cell differentiation defect occurs prematurely after Ski-induced muscle hypertrophy. Am J Physiol Cell Physiol. 2002;283(4):C1228-41.

60. Renault V, Piron-Hamelin G, Forestier C, DiDonna S, Decary S, Hentati F, et al. Skeletal muscle regeneration and the mitotic clock. Exp Gerontol. 2000; 35(6):711-9.

61. Oexle K, Kohlschutter A. Cause of progression in Duchenne muscular dystrophy: impaired differentiation more probable than replicative aging. Neuropediatrics. 2001;32(3):123-9.

62. Nicole S, Desforges B, Millet G, Lesbordes J, Cifuentes-Diaz C, Vertes D, et al. Intact satellite cells lead to remarkable protection against Smn gene defect in differentiated skeletal muscle. J Cell Biol. 2003;161(3):571-82.

63. Furling D, Coiffier L, Mouly V, Barbet JP, St Guily JL, Taneja K, et al. Defective satellite cells in congenital myotonic dystrophy. Hum Mol Genet. 2001;10(19):2079-87.

64. McFarland DC, Singh YN, Johnson AD, Pesall JE, Gilkerson KK, Vander Wal LS. Isolation and characterization of myogenic satellite cells from the muscular dystrophic hamster. Tissue Cell. 2000;32(3):257-65.

65. Garry DJ, Yang Q, Bassel-Duby R, Williams RS. Persistent expression of MNF identifies myogenic stem cells in postnatal muscles. Dev Biol. 1997;188(2):280-94.

66. Garry DJ, Meeson A, Elterman J, Zhao Y, Yang P, Bassel-Duby R, et al. Myogenic stem cell function is impaired in mice lacking the forkhead/winged helix protein MNF. Proc Natl Acad Sci USA. 2000;97(10):5416-21.

67. Irintchev A, Rosenblatt JD, Cullen MJ, Zweyer M, Wernig A. Ectopic skeletal muscles derived from myoblasts implanted under the skin. J Cell Sci. 1998;111( Pt 22):3287-97.

68. De Angelis L, Berghella L, Coletta M, Lattanzi L, Zanchi M, Cusella-De Angelis MG, et al. Skeletal myogenic progenitors originating from embryonic dorsal aorta coexpress endothelial and myogenic markers and contribute to postnatal muscle growth and regeneration. J Cell Biol. 1999;147(4):869-78. Commented in: J Cell Biol. 1999;147(4):695-8.

69. Goldring K, Partridge T, Watt D. Muscle stem cells. J Pathol. 2002;197(4): 457-67.

70. Qu-Petersen Z, Deasy B, Jankowski R, Ikezawa M, Cummins J, Pruchnic R, et al. Identification of a novel population of muscle stem cells in mice: potential for muscle regeneration. J Cell Biol. 2002;157(5):851-64.

71. Deasy BM, Jankowski RJ, Huard J. Muscle-derived stem cells: characterization and potential for cell-mediated therapy. Blood Cells Mol Dis. 2001;27 (5):924-33.

72. Goodell MA, Jackson KA, Majka SM, Mi T, Wang H, Pocius J, et al. Stem cell plasticity in muscle and bone marrow. Ann N Y Acad Sci. 2001;938:20818; discussion 218-20. 
73. Asakura A, Seale P, Girgis-Gabardo A, Rudnicki MA. Myogenic specification of side population cells in skeletal muscle. J Cell Biol. 2002;159(1):123-34.

74. Asakura A. Stem cells in adult skeletal muscle. Trends Cardiovasc Med. 2003;13(3):123-8.

75. McLoon LK, Wirtschafter JD. Continuous myonuclear addition to single extraocular myofibers in uninjured adult rabbits. Muscle Nerve. 2002;25(3): 348-58. Commented in: Muscle Nerve. 2002;25(3):311-3.

76. McLoon LK, Wirtschafter J. Activated satellite cells in extraocular muscles of normal adult monkeys and humans. Invest Ophthalmol Vis Sci. 2003;44(5): 1927-32.

77. McLoon LK, Wirtschafter J. Activated satellite cells are present in uninjured extraocular muscles of mature mice. Trans Am Ophthalmol Soc. 2002;100: 119-23; discussion 123-4.

78. Schultz E, Gibson MC, Champion T. Satellite cells are mitotically quiescent in mature mouse muscle: an EM and radioautographic study. J Exp Zool. 1978;206(3):451-6.

79. McLoon LK, Rowe J, Wirtschafter J, McCormick KM. Continuous myofiber remodeling in uninjured extraocular myofibers: myonuclear turnover and evidence for apoptosis. Muscle Nerve. 2004;29(5):707-15.

80. McLoon LK, Christiansen SP. Increasing extraocular muscle strength with insulin-like growth factor II. Invest Ophthalmol Vis Sci. 2003;44(9):3866-72.

\section{Congresso dos Centros de Ensino em Oftalmologia do Paraná e Reunião do Capífulo Brasileiro da Associação Pan-americana de Oftalmologia}

18 a 20 de Novembro de 2.004 Curitiloa - PR

INFORMAÇÕES: Tel: (41) 3024-6065

E-mail:authentictour@onda.com.br 